\title{
2018 Spinal Cord Awards
}

○ International Spinal Cord Society 2019

Spinal Cord is pleased to announce the winners of the 2018 paper awards.

The Best Review paper for 2018: Baron JS, Sullivan KJ, Swaine JM, Aspinall A, Jaglal S, Presseau J, et al. Self-management interventions for skin care in people with a spinal cord injury: part 1-a systematic review of intervention content and effectiveness. Spinal Cord. 2018;56:823-836.

The Best Original Research paper for 2018: Baunsgaard CB, Vig Nissen U, Katrin Brust A, Frotzler A, Ribeill C, Kalke Y-B, et al. Gait training after spinal cord injury: safety, feasibility and gait function following 8 weeks of training with the exoskeletons from Ekso Bionics. Spinal Cord. 2018;56:106-116.

Readers' Choice Award for Best Review paper for 2018: Martin Ginis KA, van der Scheer JW, Latimer-Cheung AE, Barrow A, Bourne C, Carruthers P, et al. Evidence-based scientific exercise guidelines for adults with spinal cord injury: an update and a new guideline. Spinal Cord. 2018;56:308-321.

Readers' Choice Award for Best Original Research paper for 2018: Itzkovich M, Shefler H, Front L, Gur-Pollack R, Elkayam K, Bluvshtein V, et al. SCIM III (Spinal Cord Independence Measure version III): reliability of assessment by interview and comparison with assessment by observation. Spinal Cord. 2017;56:46.

The Best Papers are selected by the Associate Editors and the Editor-in-Chief, while the Readers' Choice Awards are determined by the number of downloads of papers in the first six months following publication. 